\title{
Prayer and Incantation on Early Christian Amulets: Authoritative Traditions, Ritual Practices, and Material Objects
}

\author{
Joseph E. Sanzo ${ }^{1}$
}

\section{Introduction}

The academic study of pre-modern prayer and its relationship with ancient texts, rituals, and objects typically labelled "magical" (e.g., the Greek Magical Papyri [PGM], incantations, amulets, and defixiones) has greatly advanced in recent decades. Gone are the days when most classicists or ancient historians would draw an absolute line between prayer and magical incantation in agreement with the likes of Sir James Frazer (i.e., distinguishing prayer from magical incantation based on a supplicative/manipulative dichotomy). ${ }^{2}$ In fact, scholars of antiquity now generally agree that ancient prayers had much in common with contemporary amuletic formulas, incantations, and so forth.

The evidence supports this scholarly shift. In his influential essay, "Prayer in Magical and Religious Ritual," Fritz Graf deconstructed the idea that "religious" prayer and "magical" incantation in ancient Greekspeaking contexts (including the PGM) could be entirely separated on formal grounds. ${ }^{3}$ As Graf notes, some of the formularies in the PGM self-consciously refer to themselves with "prayer" language, while simultaneously using language for incantation. For instance, PGM IV.2785 is not only titled "The Prayer (euchê) to Selênê," but it also requests that she "kindly hear my sacred chants (epaoidôn)." In the

\footnotetext{
${ }^{1}$ Università Ca’ Foscari Venezia, Italy.

2 James Frazer, The Golden Bough: A Study in Magic and Religion (London: Macmillan, 1911), 220-223.

${ }^{3}$ Fritz Graf, "Prayer in Magical and Religious Ritual," in Magika Hiera: Ancient Greek Magic and Religion, ed. C. A. Faraone and D. Obbink (Oxford: Oxford University Press, 1991), 188-213.
} 
words of Graf, this text confirms that "the magician felt no difference between euchê and epôidê."4

The overlap between these respective terms is perhaps not altogether surprising in light of the meaning of euchê (i.e., a term commonly translated as "prayer") in ancient Greek. This Greek noun derives from the verb euchomai, which in its most general sense, carries the idea of making a claim. As Mary Depew has noted about the meaning of this verb within Greek human-to-human interaction: "[T] euchomai] is...to make a claim on someone in the present, whether in terms of an actual request or of recognition and acknowledgement of status." 5 When an ancient human directed his/her euchê toward a divinity, the claim typically took the form of praise, emphasizing the god's greatness and reminding that divinity of prior offerings made (e.g., a hymn of praise or a sacrifice). Radcliffe Edmonds III notes that such offerings "mark[s] the mortal's place in the relationship as the inferior and indicates that the bond of the relationship between them obligates the god to provide some return."6 Those "returns" often related to areas of life, which amulets, curse tablets (defixiones), and other ostensibly "magical" objects likewise sought to address.

The interpenetration of prayer and incantation was, of course, not unique to (late) ancient texts written in Greek. Historians of the Ancient Near East now stress the remarkable degree to which formulas, which resemble our category prayer, figured into ancient Mesopotamian incantations or witchcraft. As Daniel Schwemer puts the matter: "Is prayer a potential means of witchcraft? Many texts imply that Babylonians and Assyrians indeed considered this to be the case." 8

${ }^{4}$ Graf, "Prayer in Magical and Religious Ritual," 189 (Greek script in original).

5 Mary Depew, "Reading Greek Prayers," Classical Antiquity 16 (1997): 229-258, at 232 (cited in Radcliffe G. Edmonds III, Drawing Down the Moon: Magic in the Ancient GrecoRoman World [Princeton: Princeton University Press, 2019], 153).

${ }^{6}$ Edmonds III, Drawing Down the Moon, 154.

${ }^{7}$ In addition, there was often a fixed dimension to ancient prayers, which some scholars have associated with "magic." See, for instance, Matthias Klinghardt, "Prayer Formularies for Public Recitation: Their Use and Function in Ancient Religion," Numen 46 (1999): 10-52, at 14-20. For a critique of Klinghardt's essay, see Daniel K. Falk, "Material Aspects of Prayer Manuscripts at Qumran," in Literature or Liturgy? Early Christian Hymns and Prayers in their Literary and Liturgical Context in Antiquity, ed. C. Leonhard and H. Löhr (Tübingen: Mohr Siebeck, 2014), 33-87, at 38-40.

8 Daniel Schwemer, "Mesopotamia," in Guide to the Study of Ancient Magic, ed. D. Frankfurter (Leiden: Brill, 2019), 36-64, at 48. 
Not surprisingly, the intertwined histories of apotropaic/curative rituals and prayer persisted within late antique Christian circles. As Anastasia Maravela's recent work has shown, prayer and amuletic invocation overlapped significantly in early Christian papyri, often impeding - if not thwarting - scholarly attempts at classification. ${ }^{9}$ Many of the extant Christian phylaktêria (typically translated as "phylacteries" or "amulets") from late antique Egypt - like many of the epôidê (typically translated as "charms") and the like in the PGM ${ }^{10}-$ utilize the same structural elements as ancient euchai: e.g., invocation (invocatio) often with praise of the divine addressee; narrative (pars epica) or compressed narrative (historiola); and petition (preces). It is no wonder, therefore, that some Christian objects, such as P. Berol. 21911 (a.k.a. Suppl.Mag. 26), have prompted diverse scholarly assessments about their amuletic or prayerful functions. ${ }^{11}$

Altogether, this scholarship has demonstrated quite convincingly that the objects and practices that roughly correspond to our categories "amulet" and "prayer" possess overlapping and, in some cases, indistinguishable characteristics. Yet, as the scare quotes above suggest, the study of this relationship in antiquity is at least partially hampered by contemporary nomenclature; the ancient Greek words euchê and phylaktêrion, for instance, only partially overlap with the English terms "prayer" and "amulet" respectively. ${ }^{12}$

9 Anastasia Maravela, "Christians Praying in a Graeco-Egyptian Context: Intimations of Christian Identity in Greek Papyrus Prayers," in Early Christian Prayer and Identity Formation, ed. R. Hvalvik and K. O. Sandness (Tübingen: Mohr Siebeck, 2014), 291-324. 10 Graf, "Prayer in Magical and Religious Ritual," 189.

11 On the one hand, Theodore de Bruyn and Jitse Dijkstra have classified this object among "certain amulets and formularies" (Theodore de Bruyn and Jitse Dijkstra, "Greek Amulets and Formularies from Egypt Containing Christian Elements: A Checklist of Papyri, Parchments, Ostraka, and Tablets," BASP 48 [2011]: 163-216, no. 67). On the other hand, William Brashear has argued that this object resembles more of a prayer than a phylakterion (William Brashear, "Vier Berliner Zaubertexte [Four Magic Texts from Berlin]," ZPE 17 (1975): 25-33, at 30).

12 On the term phylaktêrion for ritual objects from late antiquity, see Peter Arzt-Grabner and Kristin De Troyer, "Ancient Jewish and Christian Amulets and How Magical They Are," Biblische Notizen 176 (2018): 5-46. Although Arzt-Grabner and De Troyer are correct in highlighting that phylakteria often simply reflects the "power that is attributed to [a ritual object," it should be noted that several phylaktêria underscore the materiality of the object by referring to the act of wearing it (e.g., P. Haun. III 51 [=Suppl.Mag. 23]; P. Coll. Youtie II 91 [Suppl.Mag. 30]; P. Turner 49 [Suppl.Mag. 31]; P. Köln inv. 851 [Suppl.Mag. 34]). 
For this reason, this chapter builds on the critical scholarship highlighted above by paying particular attention to the uses and conceptions of euchai (and its cognates) in select apotropaic and curative objects and handbooks written in Greek and Coptic from late antique Egypt. I am particularly (though not exclusively) interested in the presentation of the term euchê on those textual objects that self-identify as phylaktêria and how these and other apotropaic or curative texts explicitly or implicitly orient euchai vis-à-vis materials, substances, objects, etc. As will become evident throughout this study, late antique "Christian" practitioners imagined and deployed the Greek/Coptic term euchê (and its cognates) in diverse ways. Although some ritual specialists presented euchai in oral performative terms, others extended the semantic range of euchai to include some of the primary qualities of phylaktêria. Consequently, the term euchê could, at times, be understood as a ritualized material object in late antique Egypt.

Before I turn to the analysis proper, however, two initial qualifications are in order. First, I do not claim that the semantic range of euche on the extant amulets necessarily reflects the totality of late antique practitioners' views of this term. In fact, the semantic range of euchê on a given object does not even necessarily reflect a complete understanding of that practitioner's view of the word. Like all writers ancient and modern - practitioners did not feel compelled to provide an exhaustive account of the semantic range of the terminology at their disposal. Second, the limited scope of this essay requires that I focus only on ritual objects that explicitly use euchê in their texts. In other words, I do not treat objects that appear to us as prayers (unless they use the term euchê). Accordingly, I do not discuss objects that restrict their "prayer" language to other terms, such as the Coptic šlel. ${ }^{13}$ A more comprehensive analysis of this phenomenon is, therefore, a desideratum.

\section{Euchai on ritual objects: verbal performance and authoritative tradition}

In dialogue with broader trends in late antique Christianity, many practitioners framed euchai primarily as performative oral utterances.

\footnotetext{
13 See, for instance, Rylands 104, section 4, which includes the following formula: A prayer (slêt), when you recite it, no reptile can bit you..." See also Vienna K 8302 (Rainer, AN 191), a brief discussion of which can be found in $n .23$ below.
} 
Some practitioners confined their usage of the term euchê to a specific authoritative prayer. On several ritual objects, euchê refers to the Lord's Prayer (cf. Matt. 6:9-13). For instance, as part of his ritual text, the practitioner behind BGU III 954, a sixth-century CE Greek amulet, attempts to chase away various ailments and demonic forces through invocations of the Christian god and Saint Serenus. ${ }^{14}$ The result of such invocations, so we are told, is that he would be healthy enough to "speak the Gospel prayer" (eipein tên enaggelikên euchên). Two aspects of this phrase are particularly germane to our discussion.

First, the phrase "the Gospel prayer" clearly referred to the Lord's Prayer since this prayer of Jesus is cited in full immediately after a lacuna in the text. ${ }^{15}$ BGU III 954 is, of course, not unique in this regard. Several Greek and Coptic amulets cite the Lord's Prayer as an authoritative exemplar. Like BGU III 954, P. Duke inv. 778 cites the complete Lord's Prayer (though in the latter case it is written on the reverse side of the papyrus). ${ }^{16}$ Several other ritual objects follow suit, incorporating the entire Lord's Prayer into their texts. ${ }^{17}$ In some cases, practitioners modified - albeit only slightly - the text of the Lord's Prayer. Most importantly, several ritual specialists (including the one behind BGU III 954) insert the vocative kurie immediately before the final petition ("Lord, deliver us from evil"), presumably drawing special attention to the apotropaic contexts in which they were operating. ${ }^{18}$

14 For the editio princeps, see Ulrich Wilcken, "Heidnisches und Christliches aus Ägypten [Heathen and Christian from Egypt]," APF 1 (1901): 396-436. A Saint Serenus (along with Saint Philoxenus and Saint Biktorus) is also found in P. Oxy. 1357.

15 This amulet, which was destroyed in a bombing during World War II, apparently had a lacuna after enaggelikên euchên. The original editor, Ulrich Wilcken, tentatively reconstructed the lacuna here as "boitôs?"(in Greek script with the question mark) (Wilcken, "Heidnisches und Christliches aus Ägypten," 435; Ulrich Wilchen, ed., Ägptische Urkunden aus den Königlichen Museen zu Berlin: Griechische Urkunden, vol. 3.3 [Berlin: Weidmannsche Buchhandlung, 1903], 279). By contrast, Karl Preisendanz reconstructed this lacuna as bugiês. According to Preisendanz's reconstruction, therefore, the complete phrase originally read "the Gospel-prayer of health (enaggelikên euchên bugiês)." Since scholars no longer have access to this manuscript, a definitive conclusion to this question of reconstruction is precluded.

16 The recto of this artifact includes LXX Ps 90 - a psalm long associated with apotropaic protection within early Jewish and Christian contexts.

17 E.g., P. Schøyen I 6; P. Oxy. 4010; Athens Nat. Mus. nr. 12227 (PGM 2: 235, no. O4). P. Iand. I 6 includes an incomplete, but large portion of the Lord's Prayer (Matt. 6:9-10a; 6:13b [and doxology]).

18 BGU III 954; P Duke inv. 778; and Athens Nat. Mus. nr. 12227. 
Other objects cite only portions of the Lord's Prayer, typically the opening line or incipit. ${ }^{19}$ In light of their unique interests/preferences and the spatial limitations of the material objects at their disposal, late antique ritual specialists could formulate the incipit of this biblical/liturgical formula, so that it simply consists of "Our Father who is in heaven." 20 Alternatively, they could cite this prayer up to "holy is your name" 21 or even extend the opening line to "our daily bread." 22 In short, despite its authoritative status, the Lord's Prayer could be modified to accommodate the circumstances of a given ritual. BGU III 954 adopts this well-established strategy of modifying the Lord's Prayer, concomitantly drawing special attention to its unique authoritative status through the designation "Gospel euche."

Second, BGU III 954 stresses that the performance of the euchê took place as a singular spoken event; the practitioner uses the verb legô in its aorist infinitive form (eipein) as a complement to the future mellêsô (lit. "I will intend"), presumably emphasizing the punctiliar nature of this ritual performance. ${ }^{23}$ This emphasis on oral performance is significant since, as we will see below, other practitioners stressed the material nature of the euchê.

For some practitioners, it was not the mode of the prayer that was highlighted (e.g., oral, written, or material). Instead, it was the authoritative figure behind the prayer that came to the fore. ${ }^{24}$ In a fifth-

${ }^{19}$ For the use of incipits of biblical texts on late antique amulets, see Joseph E. Sanzo, Scriptural Incipits on Amulets from Late Antique Egypt: Text, Typology, and Theory (Tübingen: Mohr Siebeck, 2014).

20 Louvre MND 552 B.

${ }^{21}$ PSI VI 719. For discussion of the incipit of the Lord's Prayer on this amulet, see below.

22 P. Princ. II 107 (=PGM LXXXIII).

23 On the punctiliar function of the aorist (a.k.a. Constative Aorist), see Daniel Wallace, Greek Grammar Beyond the Basics: An Exegetical Syntax of the New Testament with Scripture, Subject, and Greek Word Indexes (Grand Rapids, MI: Zondervan Publishing House, 1996), 557-58. Wallace notes that this use of the aorist "describes the action in summary fashion, without focusing on the beginning or end of the action specifically" (Wallace, Greek Grammar Beyond the Basics, 557). As noted above, this infinitive is also a so-called "complementary infinitive" (see Wallace, Greek Grammar Beyond the Basics, 598-99); however, the decision to use the aorist active infinitive (instead of the present active infinitive [legein]) was likely occasioned by the practitioner's wish to emphasize the aoristic aspect (i.e., the performance of this prayer at a particular ritual event).

${ }^{24}$ It is not only the Lord's Prayer that is cited on amulets as an authoritative precedent. In the second section of Vienna K 8302 (Rainer, AN 191), the practitioner records a prayer (slêt) of the "Elijah the Tishbite" (1 Kings 17:1). Elijah is further qualified here by the appellation "the chariot of Christ," presumably a reference to the biblical story of 
or sixth-century CE Greek healing amulet for an unmentioned woman (G. Vitelli 365), the practitioner highlights "the prayers and intercession (euchais k[ai] presbeia) of the ever-virgin mother, the mother of god." 25 The text of the amulet begins with the Trishagion (1. 1), followed by a narrative that refers to select miracles of God in the Gospels (i.e., the raising of Lazarus and the healing of Peter's mother-in-law) and "many unmentioned healings in addition to those they report in the sacred Gospels (en tois ierois enaggeliois)." 26 The practitioner then focuses on the material object, demanding healing - with an imperative (iasai) - for the female who "wears" (phorousan) the "divine amulet" (to theion phylaktêrion). Here we have our first instance of the occurrence of the term euchê on an object self-identified as a phylaktêrion. The way the practitioner distinguishes these terms is instructive. Mary's euchai (and her intercession) function as the means by which this healing occurs; the practitioner certainly conceives of the datives euchais and presbeia in the instrumental sense ("by means of the prayers and intercession"). ${ }^{27}$ It is worth stressing that the practitioner has clearly distinguished the materiality of the object (the phylakterion to be worn) from the incorporeal prayers to be spoken by Mary in her present intercessory role as the ever-virgin mother of god. ${ }^{28}$

the prophet being taken to heaven on chariots of fire (2 Kings 2:11-12). For the text of this prayer, see Viktor Stegemann, ed., Die koptischen Zaubertexte der Sammlung Papyrus Eræ̧herzog Rainer in Wien (Heidelberg: Carl Winters Universitätsbuchhandlung, 1934), 7076.

25 For the editio princeps, see Girolamo Vitelli, "Noterelle papirologiche," Bulletin de la Société Archéologique d'Alexandrie 23 (1928): 287-302, at 300-301, no. 22. For the translation of this artifact, see Marvin Meyer and Richard Smith, eds., Ancient Christian Magic: Coptic Texts of Ritual Power (Princeton, NJ: Princeton University Press, 1999), 38 (no. 13). The translations of all Greek and Coptic ritual texts in this essay have been taken from Meyer and Smith, Ancient Christian Magic, unless otherwise indicated.

26 This particular phrase is rather lacunose in the original manuscript. As I have highlighted elsewhere, this final phrase reflects the metonymic nature of general references to healing (Sanzo, Scriptural Incipits, 55-56).

27 For a similar approach to the efficacy of prayer, see also P. Oxy. 1151. For the instrumental dative, see Herbert W. Smyth, A Greek Grammar for Colleges (Harvard: Harvard University Press, 1956), 346-49.

28 Mary also emerges as an authoritative figure in other prayers. For instance, she figures in a prayer in Brit. Lib. Or. 6796(2, 3, 1): "Maria, who is in the presence of god the father, who dwells in [the heaven] of light, raised her eyes up to heaven to the compassionate god who resides in the holy [tabernacle], saying, 'I praise [you. I glorify] you. I invoke you today...." Variants of the text in Brit. Lib. Or. $6796(2,3,1)$ had a 


\section{Materiality and Euchai on select Phylaktêria}

We have just seen how some late antique ritual objects presented the euchê as an oral, performative utterance, whether that performance consists of the recitation of Jesus' authoritative euchê by the client (BGU III 954) or of the euchai of a heavenly intercessor, such as Mary Theotokos (G. Vitelli 365). Other objects complicate the relationships between verbal, scribal, and material domains. P. Cairo 45060, a sixthor seventh-century CE Coptic ritual handbook that was discovered in a monk's cell near Deir el-Bakhit (Thebes), instructs the ritual performer to recite a proseuchê over various materials and substances. ${ }^{29}$ This text opens with an extended text, which includes a host of angelic, divine, and ritual names (e.g., Athariêl, Sabaôth, Abrasax, Anaêl, Gabriêl, Ablanatha, and Abra) and the following request: "Listen to me, holy and glorious god, and fulfill for me the request of my heart and the petition of my lips, for I am a descendent of Atamas Kanlahaêl Antanaêl Seblêl. Listen to me, Amen" (1l. 19-22). This text seems to be subsequently identified as the proseuchê that is to be applied to a variety of concerns, often in connection with material substances. For instance, the reader is instructed to do the following "for a hindrance" (etbe ousašt : : "Utter the prayer (teprosêchê [read: teproseuchê]) three times over sulfur and pitch (and) oil of henna, and thus it will happen. You must prepare it on the fifteenth of the month" (11. 25-27). Following an ancient Egyptian tradition that dates at least as far back as the Ramessid period (Dynasties 19-20, ca. 1300-1086 BCE),30 the practitioner has instructed the oral performance to take place over certain substances in this case, sulfur (outhên), pitch (oulamjat), and oil of henna (kypron). This practitioner, however, has also placed temporal limits on the efficacy of this prayer-ritual: it must be prepared on the fifteenth of the

long afterlife, appearing on such objects as P. Heid. inv. Kopt. 685. For discussion of the development of this prayer, see Marvin Meyer, The Magical Book of Mary and the Angels (P. Heid. Inv. Kopt. 685): Text, Translation, and Commentary (Heidelberg: Universitätsverlag C. Winter, 1996), 1-8.

${ }^{29}$ For the editio princeps, see Angelicus Kropp, ed., Ausgewählte koptische Zaubertexte, 3 vols. (Brussels: Édition de la Fondation égyptologique Reine Élisabeth, 1930-31), 1:50-54 (no. K). For an English translation, see Meyer and Smith, Ancient Christian Magic, 27073. On the parallels between P. Cairo 45060 and EA 10391, see n. 39 below.

${ }^{30}$ For a discussion of this practice, see Jacco Dieleman, "The Materiality of Textual Amulets in Ancient Egypt," in The Materiality of Magic, ed. D. Boschung and J. Bremmer (Wilhelm Fink: Paderborn. 2015), 23-58, at 34-36. 
month. Such restrictions are not unusual in ancient magical recipes. ${ }^{31}$ PGM IV.26-51 similarly instructs: "On the third of the month (têtritê tês selênês), go to a place from which the Nile has recently receded, before anyone walks on the area that was flooded." 32

In several other instances, this practitioner blurs the traditional lines scholars have drawn between text, material, and context. In 11. 31-34, the monk instructs a potential client concerned with eye disease to "(take) a little aged vinegar, catch a sparrow, and write on it the first name of the prayer (ngshai ejôf mpšarrt nran nteproseuchê). Fill its eyes with aged vinegar, remove them, and let it go (?). You must prepare it on the eighth (day) of the month." There are several aspects of this specific recipe that are of great interest. For our purposes, however, I would like to focus on two interrelated points. First, the instruction to write the first name of the prayer on a sparrow, whose eyes are initially filled with aged vinegar (bmjas) and then removed, adds scribal, material, and gestural dimensions to this proseuchê. Indeed, the performer not only needs to inscribe a word from this prayer, but $\mathrm{s} /$ he also needs to inscribe it on a living creature, while mutilating its body with the help of other material substances.

Second, the instruction to inscribe the first name of the euchê (i.e., Athariêl) onto the sparrow also embeds it within a longstanding metonymic tradition in late antique ritual contexts. The use of initial words or opening lines (incipits) was well established in ancient near eastern ritual cultures. ${ }^{33}$ By the time the practitioner behind P. Cairo 45060 put together this handbook, the use of incipits of biblical texts, especially the opening lines of the Gospels, LXX Ps 90:1, and the first words of the Lord's Prayer had become quite common. ${ }^{34}$ We have

31 For a recent discussion of the role of temporality in ancient magical contexts (with a particular emphasis on the Greek Magical Papyri), see Andrea Salayová, "Aspects of Temporality in the Greek Magical Papyri," Graeco-Latina Brunensia 23 (2018): 181-94. To be sure, the specification of times and dates for euchai was common for rituals typically identified as "religious" (see Edmonds III, Drawing Down the Moon, 152).

32 Translation by Hubert Martin, Jr. in Hans Dieter Betz, ed., The Greek Magical Papyri in Translation Including the Demotic Spells, vol. 1: Texts with an Updated Bibliography (2 ${ }^{\text {nd }}$ edition; Chicago: University of Chicago Press, The University of Chicago Press, 1992), 37.

33 See, for instance, Mark J. Geller, "Incipits and Rubrics," in Wisdom, Gods and Literature: Studies in Assyriology in Honour of W. G. Lambert, ed. A. R. George and I. L. Finkel (Winona Lake: Eisenbrauns, 2000), 225-58.

34 Sanzo, Scriptural Incipits. 
already seen how the opening line of the Lord's Prayer was used on various amulets from late antiquity. The use of the opening words seems to have, in many cases, functioned in a part-for-whole relationship with the Lord's Prayer itself. ${ }^{35}$ PSI VI. 719 appears to explicitly highlight this incipit quality of the reference; a lacuna immediately following "onoma sou" ("your name") has been reasonably reconstructed as originally reading kai ta hexês ("and the rest"). ${ }^{36}$ The likelihood that this reconstruction is correct is suggested by the fact that this very phrase is used on this amulet after the opening line of LXX Ps 90, which occurs immediately before the incipit of the Lord's Prayer. ${ }^{37}$ Furthermore, a kappa and an alpha (presumably the first two letters of kai ["and"]) are visible in the extant manuscript. Questions surrounding the validity of this particular reconstruction of the lacuna in PSI VI. 719 notwithstanding, the instruction in P. Cairo 45060 to write the first name of the prayer suggests that the practitioner intended this word to invoke metonymically the totality of his proseuchê. It is unclear whether the instruction to use the incipit of his own proseuchê was meant to add legitimacy to it by mimicking the well-known use of the opening lines of the Lord's Prayer or - perhaps more likely - was merely occasioned by the scribal limitations of the required object (the sparrow).

However, P. Cairo 45060 was not the only ritual object whose text traversed the boundary between materiality and oral performance in complex ways. In the so-called "London Hay Cookbook" (EA 10391), the practitioner first makes a material distinction between ritual objects (nephêlaktêrion [read: nephylaktêrion]) and his euchê, simultaneously underscoring the ritual performance of the latter. ${ }^{38}$ In 1.56 , the

35 Ibidem, 165-68.

36 It was reconstructed in the editio princeps, Girolamo Vitelli, Pubblicazioni della Società Italiana per la ricerca dei papiri greci e latini in Egitto: Papiri greci e latini, vol. 6 (Florence: Pubblicazioni della Società Italiana, 1920), 151-52 (no. 719).

${ }^{37}$ For the implications of the phrase kai ta hexês on PSI VI 719 for the metonymic use of scriptural incipits on late antique amulets more generally, see Sanzo, Scriptural Incipits, 168-71. The metonymic relationship between trigger and target for incipits of single-unit texts, such as the Lord's Prayer and individual psalms, should be distinguished from the metonymic relation operative in cases in which incipits of larger textual units (e.g., the Gosples) are used.

38 Kropp, Ausgewählte koptische Zaubertexte, 1:55-62 (no. M). A new edition of this handbook is being prepared by Michael Zellmann-Rohrer. I am grateful to Prof. Zellmann-Rohrer for sharing a pre-publication version of this handbook (along with an English translation). I follow here his updated version and English translation. 
practitioner instructs the performer to "write the amulets; bind them to your thumb; utter the prayer (teeuchê)." This formula gives the impression that the practitioner conceptualized phylakteria in both scribal and material terms, while an euchê was thought to be something that is spoken $(\hat{o s})$.

But matters are not so simple. This euchê, which seems to be the balance of the lengthy text that proceeds the formula in 1. 56, includes separate invocations of the three guardians (Amanou, Pourat, Phourani) and Horus, both of which, inter alia, request that these preternatural entities "leave every place where you are and come to me, to the place where I am." 39 It is worth noting that the entreaty of Horus also refers to the materials that form an offering to this preternatural entity: "for I adjure you...that at the moment you turn your gaze upon the offering of radish-oil and the pad of lamb's wool and the wild lupine...that they assist the things I will undertake, I NN, yes, yes, quickly, quickly" (ll. 34-36). This adjuration is followed by a list of substances, which includes incense (libanos) and mastic (mastiche).

In addition to the requests to the three guardians and Horus, this euchê also includes an interesting invocation of the "Syrian" (psyros) who is further named "ANBERSAOU ARARAPH KATTHOU PETAKATHTHA ARARAPH” (1. 39) - which requests that this entity:

...leave behind the places in which you are and descend upon the cup of water (peapot nmoou) placed before me and fill it with light for me like the sun and the moon sevenfold, and fill my eyes with divinity and my vision with light, that you reveal every mystery about which I shall inquire of you, yes, yes, for I adjure you by the great, true name of the father, whose name is Aiô Sabaôth... (EA 10391, 1l. 40-45)

This invocation is likewise followed by the instruction to include an offering of mastic. The material substances named in this euchê, however, do not correspond to those found in the recipes.

It is worth underscoring this discrepancy or tension between the material objects and substances that are listed in the composite prayer itself and those in the specific recipes that follow. As already seen - and

\footnotetext{
39 As Angelicus Kropp has noted, the invocation of the three guardians seems to have been based on eucharistic liturgy (Kropp, Ausgewählte koptische Zaubertexte, 3:65-66; 67).
} 
as becomes even clearer from several recipes in this "cookbook" - the euchê is to be recited over various material substances. For instance, in a recipe designed to remove a person from his house, the text instructs the performer to "recite the prayer (teeuchê) over wild mustard (ousinapon nakrion) and saltwater (oumoou nbmou), cast them at the door of his house" (11. 79-80). Wild mustard and saltwater are not found in the prayer. It is possible - perhaps even likely - that the discrepancy between the materials and substances (i.e., the cup of water) found in the prayer itself and those in the recipes (e.g., wild mustard and saltwater) reflect the multiple redactional layers behind the text as we have it. ${ }^{40}$ Whatever the case might have been, the recipe in its current form in EA 10391 seems to require the performer to speak about certain material substances and objects (e.g., incense, mastic, and a cup of water [with no mention of salt]), while performing a ritual that involved the manipulation of other substances (i.e., wild mustard and saltwater [with no mention of a cup]).

In sum, EA 10391 attests to the complex and perhaps even contradictory mergers, combinations, and ruptures of scribal, verbal, and material domains that might take shape in ritual euchai. Despite these intricate arrangements of material, textual, and verbal spheres, however, the practitioner presupposed a clear distinction between euchai and phylaktêria.

Yet, not even this distinction between euchai and phylakteria was always clearly maintained. In Leiden, Ms. AMS 9, a fifteen-folio Coptic ritual handbook that has been diversely dated between the sixth and eighth centuries $\mathrm{CE},{ }^{41}$ the semantic fields of the euchê (and its cognates) and the

\footnotetext{
40 There is evidence that this practitioner has incorporated into his euchê elements or traditions that circulated in other contexts. For instance, in an unpublished edition of EA 10391, Prof. Zellmann-Rohrer has properly highlighted the close parallels - both in terms of the format (the listing of divine names) of the euchê and of its specific prescriptions (e.g., the instructions to "contemplate" [logeze] and to speak the prayer three times) - between EA 10391 and P. Cairo 45060 (see above). Such parallels might suggest that these practitioners were both drawing from a common ritual tradition in late antique Egypt.

41 See Armando Petrucci, "From the Unitary Book to the Miscellany," in Writers and Readers in Medieval Italy: Studies in the History of Written Culture by A. Petrucci, ed. and trans. C. M. Radding (New Haven: Yale University Press, 1995), 1-18, at 10; John A. Szirmai, The Archaeology of Medieval Bookbinding (Aldershot: Ashgate, 1999), 43 n. 6; Jacques van der Vliet, "Christian Spells and Manuals from Egypt," in Guide to the Study of Ancient Magic, ed. D. Frankfurter (Leiden: Brill, 2019), 322-50, at 329.
} 
phylaktêrion overlap almost entirely with one another. ${ }^{42}$ The codex, which might have been composed by a monk, ${ }^{43}$ includes a relatively wide range of Christian texts (e.g., the Abgar-Jesus correspondence and the Prayer of Judas Cyriacus). In addition to such well-known writings, one can find in this codex a text entitled "Prayer and Exorcism of Gregory," versions of which, to be sure, are attested in several medieval Greek manuscripts. ${ }^{44}$ The practitioner falsely attributes this prayer ([pros-]euchê) to an authoritative character, Saint Gregory, ${ }^{45}$ and deploys what Paul Mirecki has called an "ego-proclamation," whereby the performer takes on the persona of an authoritative character through first-person speech. ${ }^{46}$ The text begins with the following words: "A prayer (euchê) and exorcism that I wrote, I, Gregory, the servant of the living god, to become an amulet (phylaktêrion) for everyone who will receive and read it ... (Leiden, Ms. AMS 9, 1r, 1-13)." For this practitioner, therefore, the efficacy of the prayer is at least partially contingent upon the ostensible origins of this prayer in an authoritative Christian figure (Gregory). In this way, the codex finds kinship with G. Vitelli 365 (discussed above), which likewise highlights the authoritative person (Mary) behind the euchai. Of course, this euchê is slightly different from the one found in G. Vitelli 365 in that the practitioner here has attributed antiquity and authority to a specific prayer (perhaps, his own innovation) through

\footnotetext{
42 For the editio princeps, see Willem Pleyte and Pieter A. A. Boeser, eds., Manuscrits coptes du Musée d'antiquités des Pays-Bas à Leide (Leiden: Brill, 1897), 441-79. For a discussion of some of the primary textual and editorial problems with this codex (including its incorrect pagination among editors), see Joseph E. Sanzo, "At the Crossroads of Ritual Practice and Anti-Magical Discourse in Late Antiquity: Taxonomies of Licit and Illicit Rituals in Leiden, Ms. AMS 9 and Related Sources," Magic, Ritual, and Witchcraft 14 (2019): 230-54.

43 Theodore de Bruyn, Making Amulets Christian: Artefacts, Scribes, and Contexts (Oxford: Oxford University Press, 2017), 87.

${ }^{44}$ van der Vliet, "Christian Spells and Manuals from Egypt," 329.

45 Richard Smith has hypothesized that this Gregory was either Gregory of Naziansus or Gregory Thaumaturgus (Smith and Meyer, Ancient Christian Magic, 311). Jacques van der Vliet associates this prayer with the latter figure and provides a brief discussion of the prayer's medieval afterlife (van der Vliet, "Christian Spells and Manuals from Egypt," 329).

46 Paul Mirecki, "Manichaean Allusions to Ritual Magic: Spells for Invisibility in the Coptic Kephalaia," in The Light and the Darkness: Studies in Manichaeism and its World, ed. P. A. Mirecki and J. Beduhn (Leiden: Brill, 2001), 173-80, at 176.
} 
pseudepigraphy. ${ }^{47}$ One finds a similar technique on Brit. Lib. Or. 6796(4), 6796, where the practitioner presents a proseuchê (based largely on the Gospel of Matthew's passion account), which Jesus is supposed to have said while he was hanging on the cross. ${ }^{48}$

However, my interest in this practitioner's approach to the euchê is not limited to his use of pseudepigraphy. As we have seen, the practitioner frames this Prayer and Exorcism of Gregory as an euchêand also as an exorcism (eksorgismos [read: eksorkismos]) - that becomes a phylaktêrion. In another section, the text requests that god "guard all the limbs of those who possess this prayer (proseuchê), who not only recite it but also use it as an amulet" ( $3 \mathrm{v}, 1.22-4 \mathrm{r}, 1.2) .{ }^{49}$ The healing properties of this euchê are likewise stressed: "Holy trinity, spare everyone who has this seal (sphragis), and those who have this prayer (pro[s]euchê), and every place in which it is published and become for them an amulet (phylaktêrion) and aid (nboêthêma), a cure-all for every pain of any sort" $(7 \mathrm{r}, 1.23-7 \mathrm{v}, 1.4)$. These passages demonstrate that an euchê for this practitioner was not limited to the verbal sphere, but could also be used as a protective or healing object. On account of this practitioner's complex understanding of euchai, he also highlights the material qualities of his euchê in ways that erase clear lines between euchai and phylaktêria. Most importantly, the practitioner claims that his proseuchê can be deposited as part of apotropaic rituals: "I adjure you violent deeds...that you flee far away and not at all continue to stay in the place where this prayer (proseuchê) is deposited" (4r, 1l. 5-26). This theme

47 This practice resonates with Eric Hobsbawm's notion of the "invented tradition" (Eric Hobsbawm, "Introduction," in The Invention of Tradition, ed. E. Hobsbawm and T. Ranger [Cambridge: Cambridge University Press], 1992, 1-14). For the relevance of Hobsbawm's notion of "invented tradition" for the ancient world, see Albert I. Baumgarten and Marina Rustow, "Judaism and Tradition: Continuity, Change and Innovation," in Jewish Studies at the Crossroads of Anthropology and History: Authority, Diaspora, Tradition, ed. R. Boustan, O. Kosansky and M. Rustow (Philadelphia: University of Pennsylvania Press, 2011), 207-37.

48 Kropp, Ausgewählte koptische Zaubertexte, 1:47-50 (no. J). For discussion of this prayer, see Joseph E. Sanzo, “The Innovative Use of Biblical Traditions for Ritual Power: The Crucifixion of Jesus on a Coptic Exorcistic Spell (Brit. Lib. Or. 6796[4], 6796) as a Test Case," Archiv für Religionsgeschichte 16 (2015): 67-98, at 71-74.

49 The practitioner seems to emphasize this transformative function of his euchê in another lacunose passage, which has been reconstructed to read: "You (Jesus Christ) must [enliven] everyone who will [recite] this prayer or [who will] put it on himself as an [amulet]." 
continues in another section of the text, in which the practitioner request protection from "everyone near whom this prayer (proseuchê) shall be recited, or every place where it will be deposited..." (3r, ll. 912). Once again, we read: "For every one who shall take this prayer (proseuchê) to the place where this prayer is deposited shall not be afraid" (5v, 1l. 24-28). In sum, this ritual expert classified the euchê (and its cognates) in both verbal and material terms.

\section{Conclusions}

This chapter explored - albeit briefly - the diverse uses of the term euchê and its distinctions, overlaps, and even synonymy with the word phylaktêrion on apotropaic and curative devices from late antique Egypt. This comparative enterprise has required that I pay special attention to the ways in which materiality figured into these ritual objects - whether explicitly highlighted or only implicitly assumed. As we have seen, practitioners not only understood euchai as performative utterances, but in certain cases situated euchai at the margins of oral, scribal, and material domains. In one Coptic exemplar, the practitioner even framed the (pros)euchê in quintessentially material terms, virtually erasing any distinction between the euchê and the phylaktêrion.

This glimpse into the native terminology of late antique practitioners ought to inform our scholarly usage of the rubric "prayer," especially as it relates to the study of early Christian lived religion. Indeed, the evidence surveyed in this essay demonstrates that early Christians probably even early Christian monks - not only "said" their euchai, they also "touched" them.

\section{References}

Arzt-Grabner, Peter and Kristin De Troyer. "Ancient Jewish and Christian Amulets and How Magical They Are." Biblische Notizen 176 (2018): 5-46.

Baumgarten, Albert I. and Marina Rustow. "Judaism and Tradition: Continuity, Change and Innovation." In Jewish Studies at the Crossroads of Anthropology and History: Authority, Diaspora, Tradition, ed. R. Boustan, O. Kosansky and M. Rustow, 207-37. Philadelphia: University of Pennsylvania Press, 2011.

Brashear, William. "Vier Berliner Zaubertexte." ZPE 17 (1975): 25-33. 
Betz, Hans Dieter, ed. The Greek Magical Papyri in Translation Including the Demotic Spells, vol. 1: Texts with an Updated Bibliography. 2nd edition; Chicago: University of Chicago Press, 1992.

De Bruyn, Theodore. Making Amulets Christian: Artefacts, Scribes, and Contexts. Oxford: Oxford University Press, 2017.

De Bruyn, Theodore and Jitse Dijkstra. "Greek Amulets and Formularies from Egypt Containing Christian Elements: A Checklist of Papyri, Parchments, Ostraka, and Tablets." BASP 48 (2011): 163-216.

Depew, Mary. "Reading Greek Prayers." Classical Antiquity 16 (1997): 229-258.

Dieleman, Jacco. "The Materiality of Textual Amulets in Ancient Egypt." In The Materiality of Magic, ed. D. Boschung and J. Bremmer, 23-58. Wilhelm Fink: Paderborn, 2015.

Edmonds, Radcliffe G. Drawing Down the Moon: Magic in the Ancient Greco-Roman World. Princeton: Princeton University Press, 2019.

Falk, Daniel K. "Material Aspects of Prayer Manuscripts at Qumran." In Literature or Liturgy? Early Christian Hymns and Prayers in their Literary and Liturgical Context in Antiquity, ed. C. Leonhard and H. Löhr, 33-87. Tübingen: Mohr Siebeck, 2014.

Frazer, James. The Golden Bough: A Study in Magic and Religion. London: Macmillan, 1911.

Graf, Fritz. "Prayer in Magical and Religious Ritual." In Magika Hiera: Ancient Greek Magic and Religion, ed. C. A. Faraone and D. Obbink, 188-213. Oxford: Oxford University Press, 1991.

Geller, Mark J. "Incipits and Rubrics." In Wisdom, Gods and Literature: Studies in Assyriology in Honour of W. G. Lambert, ed. A. R. George and I. L. Finkel, 225-58. Winona Lake: Eisenbrauns, 2000.

Hobsbawm, Eric. "Introduction." In The Invention of Tradition, ed. E. Hobsbawm and T. Ranger, 1-14. Cambridge: Cambridge University Press, 1992.

Klinghardt, Matthias. "Prayer Formularies for Public Recitation: Their Use and Function in Ancient Religion." Numen 46 (1999): 10-52.

Kropp, Angelicus ed. Ausgewählte koptische Zaubertexte, 3 vols. Brussels: Édition de la Fondation égyptologique Reine Élisabeth, 1930-31.

Maravela, Anastasia. "Christians Praying in a Graeco-Egyptian Context: Intimations of Christian Identity in Greek Papyrus Prayers." In 
Early Christian Prayer and Identity Formation, ed. R. Hvalvik and K. O. Sandness, 291-324. Tübingen: Mohr Siebeck, 2014.

Meyer, Marvin. The Magical Book of Mary and the Angels (P. Heid. Inv. Kopt. 685): Text, Translation, and Commentary. Heidelberg: Universitätsverlag C. Winter, 1996.

Meyer, Marvin and Richard Smith, eds. Ancient Christian Magic: Coptic Texts of Ritual Power. Princeton, NJ: Princeton University Press, 1999.

Mirecki, Paul. "Manichaean Allusions to Ritual Magic: Spells for Invisibility in the Coptic Kephalaia." In The Light and the Darkness: Studies in Manichaeism and its World, ed. P. A. Mirecki and J. Beduhn, 173-80. Leiden: Brill, 2001.

Petrucci, Armando. "From the Unitary Book to the Miscellany." In Writers and Readers in Medieval Italy: Studies in the History of Written Culture, ed. A. Petrucci, and trans. C. M. Radding, 1-18. New Haven: Yale University Press, 1995.

Pleyte, Willem and Pieter A. A. Boeser, eds. Manuscrits coptes du Musée d'antiquités des Pays-Bas à Leide. Leiden: Brill, 1897.

Salayová, Andrea. "Aspects of Temporality in the Greek Magical Papyri." Graeco-Latina Brunensia 23 (2018): 181-94.

Sanzo, Joseph E. Scriptural Incipits on Amulets from Late Antique Egypt: Text, Typology, and Theory. Tübingen: Mohr Siebeck, 2014.

—. "The Innovative Use of Biblical Traditions for Ritual Power: The Crucifixion of Jesus on a Coptic Exorcistic Spell (Brit. Lib. Or. 6796[4], 6796) as a Test Case." Archiv für Religionsgeschichte 16 (2015): 67-98.

—_. "At the Crossroads of Ritual Practice and Anti-Magical Discourse in Late Antiquity: Taxonomies of Licit and Illicit Rituals in Leiden, Ms. AMS 9 and Related Sources." Magic, Ritual, and Witchcraft 14 (2019): 230-54.

Schwemer, Daniel. "Mesopotamia." In Guide to the Study of Ancient Magic, ed. D. Frankfurter, 36-64. Leiden: Brill, 2019.

Smyth, Herbert W. A Greek Grammar for Colleges. Harvard: Harvard University Press, 1956.

Stegemann, Viktor, ed. Die koptischen Zaubertexte der Sammlung Papyrus Erzherzog Rainer in Wien. Heidelberg: Carl Winters Universitätsbuchhandlung, 1934. 
Szirmai, John A. The Archaeology of Medieval Bookbinding. Aldershot: Ashgate, 1999.

Van der Vliet, Jacques. "Christian Spells and Manuals from Egypt.” In Guide to the Study of Ancient Magic, ed. D. Frankfurter, 322-50. Leiden: Brill, 2019.

Vitelli, Girolamo. Pubblicazioni della Società Italiana per la ricerca dei papiri greci e latini in Egitto: Papiri greci e latini, vol. 6. Florence: Pubblicazioni della Società Italiana, 1920.

—. "Noterelle papirologiche." Bulletin de la Société Archéologique d'Alexandrie 23 (1928): 287-302.

Wallace, Daniel. Greek Grammar Beyond the Basics: An Exegetical Syntax of the New Testament with Scripture, Subject, and Greek Word Indexes. Grand Rapids, MI: Zondervan Publishing House, 1996.

Wilcken, Ulrich. "Heidnisches und Christliches aus Ägypten." APF 1 (1901): 396-436.

Griechische Urkunden, vol. 3.3. Berlin: Weidmannsche Buchhandlung, 1903.

\section{Acknowledgments}

This essay was completed as part of the project, "Early Jewish and Christian Magical Traditions in Comparison and Contact." This project has received funding from the European Research Council (ERC) under the European Union's Horizon 2020 research and innovation programme (grant agreement No. 851466 EJCM). 